\title{
Review on Volumes of Foreign Economic Operations with Agricultural Products
}

\author{
Natalie Yuriivna Shevchenko, Olena Oleksandrivna Lemishko \\ Department of Finance, National University of Life and Environmental Sciences of Ukraine, Kyiv, Ukraine \\ Email address: \\ 200582_aukr.net (N. Y. Shevchenko), elena.lemishko@gmail.com (O. O. Lemishko)
}

\section{To cite this article:}

Natalie Yuriivna Shevchenko, Olena Oleksandrivna Lemishko. Review on Volumes of Foreign Economic Operations with Agricultural Products. International Journal of Economics, Finance and Management Sciences. Special Issue: Taxation of Foreign Economic Operations with Agricultural Products. Vol. 7, No. 6, 2019, pp. 222-226. doi: 10.11648/j.jjefm.20190706.17

Received: November 5, 2019; Accepted: November 29, 2019; Published: December 25, 2019

\begin{abstract}
One of the main tasks for the state is approximation of the Ukrainian legislation to the EU Member States' legislation in the area of trade and economic relations. For Ukraine, as an independent state, which today faces serious economic problems, the important task is to decide how to take the path of sustainable development of the economy, tax and financial system in the context of the European integration. Ukrainian agriculture and food industry are not sufficiently integrated into the international trading system, as evidenced by the low percentage of exports and imports of agricultural and food products in gross agricultural production. In recent years, in Ukraine, the percentage of exports of agricultural and food products was 16\%, compared to 25\% in Poland and 53\% in France and Germany. Therefore, it is very important for Ukraine to improve the level of competitiveness for domestic products. The article describes the dynamics of agri-food exports and imports into countries, and it has been found a negative trade balance. The commodity structure of exports and imports of Ukrainian agricultural products is discussed. The reasons for the steady growth of imports are substantiated. Measures to improve the trade balance have been proposed.
\end{abstract}

Keywords: Foreign Economic Activity and Operations, Agricultural Products, Export, Import

\section{Introduction}

The development of high-tech industries requires the creation of a new, market-based infrastructure for foreign economic business. Meanwhile, the foreign trade activity of agricultural production is directed towards entering the world agricultural market and is a component in the economic circulation of products between the countries and economic unions.

In addition, export and import of products have always been and will be the most effective means to attract investment, efficient technologies, and therefore expanding sales of products into foreign markets. Therefore, further enhancing the role of taxation of foreign economic operations in the country's agricultural complex should become one of the strategic directions in agricultural policy.

The theoretical basis for understanding the problems of foreign economic operations is embedded in the scientific works of such famous Ukrainian economists as O. Kireeva [1], A. Kredisov [2], Shpichak [3], A. Filippenko [4], O. and others.

\section{Results and Discussion}

Having a large agricultural sector, Ukraine is and will continue to be a major exporter of food and agricultural products, especially within the Commonwealth of Independent States (CIS). In late 1990, Ukraine became a regular supplier of cereals and oilseeds into world markets. The majority of Ukrainian cereals were exported to the Middle East, Eastern Europe and EU Member States. Since 2001, Ukraine has become a major exporter of dairy products, primarily to Russia, CIS countries, Japan and the Middle East. Export volumes of processed products and high value-added products are insignificant but growing rapidly.

Demand for the vast majority of essential commodities is met through domestic production. However, it is difficult for local agricultural producers to compete with imported ones because of high import duties and a high total level of food production efficiency.

Despite the pace of development, agriculture still remains 
a small share in total volume of gross domestic product (GDP). In 2003, agriculture amounted to $13 \%$ of GDP, while the food industry amounted to $7 \%$. In 2009 , the share of agriculture in GDP was 15\%, and in 2018 - again 13\% [5].

Foreign trade plays an important role in the Ukrainian economy. The trend during 2012-2016 was a decrease in export revenue from goods while simultaneous reduction in export of agricultural products. Despite the general negative trend, in 2017 an increase in exports was observed, including agricultural products. In 2017, total exports amounted to US\$ 43.3 billion that is $19 \%$ more than in 2016. And according to the results of 2018, total exports of products from Ukraine amounted to $\$ 47.3$ billion, which is $9.2 \%$ more compared to 2017 [5].

The dynamics of agri-food exports showed a similar trend as the rest of exported goods, however, the pace of reduction of agri-food exports was lower than the total one and, despite the recession after the 2012/13 crisis, the growth of supply was already observed in 2016. The historically record volume of agri-food exports was observed in 2012, amounted to about $\$ 17.9$ billion. However, this indicator was exceeded - by the results of 2018 the agri-food products were sold abroad for $\$ 18.6$ billion. Thus, for the last 10 years, the export of agri-food products from Ukraine has doubled [5, 6].

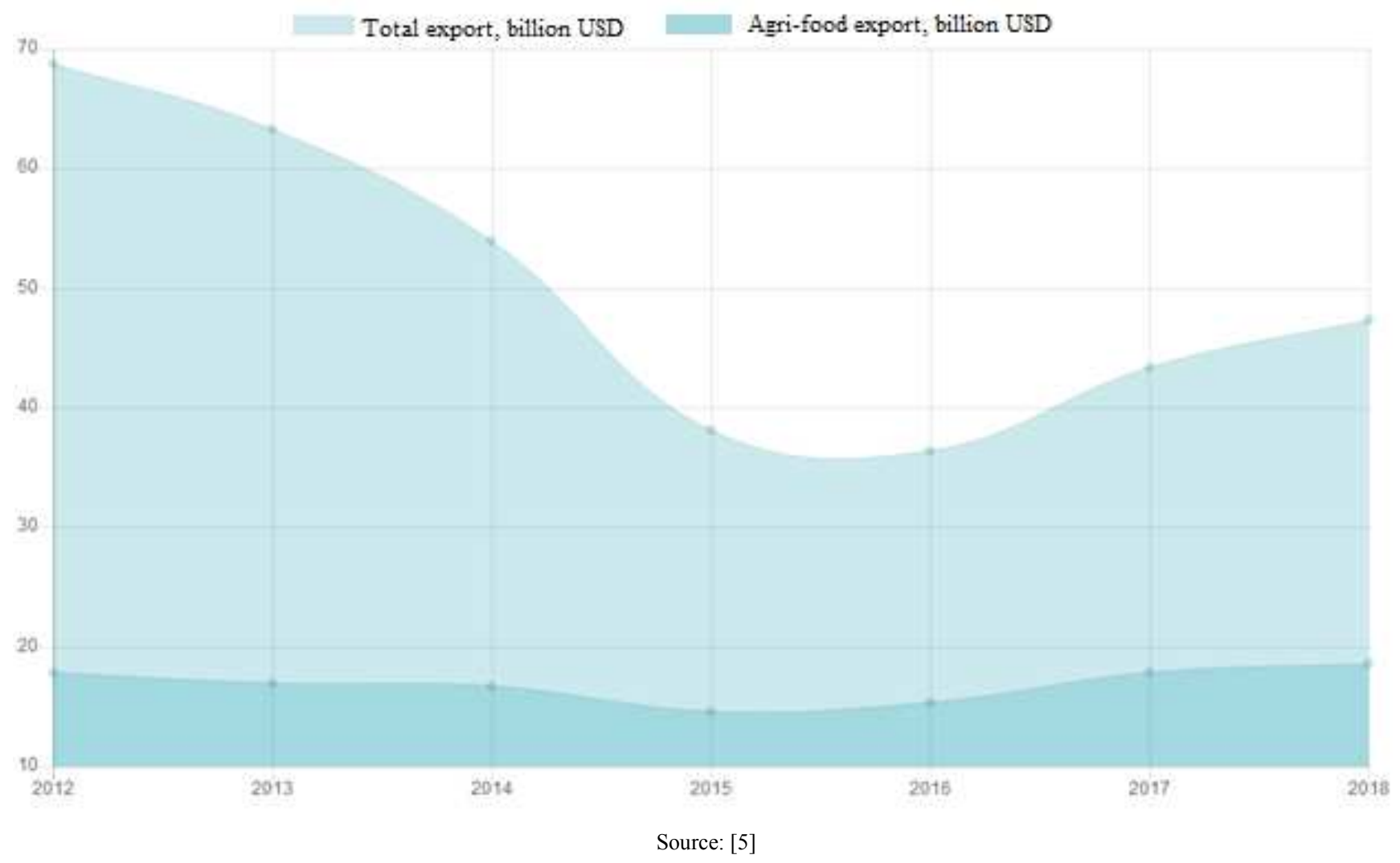

Figure 1. Dynamics of volumes in total export and Ukraine's agricultural sector export, 2012-2018 (billion USD).

Over the last 5 years, the share of agricultural products in the structure of Ukraine's export revenue has increased from $31 \%$ in 2014 to $39.3 \%$ in 2018 . However, it is worth noting that the basis of agricultural exports is still raw material exports, namely products of plant origin - wheat, corn, barley and soybeans. The share of these products in the structure is about $55 \%$ [5].

Sunflower oil takes the lion's share in agricultural exports, its sales volume amounted to $\$ 4.1$ billion in 2018 . Ukraine is a world leader in the production and export of sunflower oil for several years. Other key positions occupy cereal crops (corn, wheat, barley), and also oilseeds (soybeans) and oilseed processed products (sunflower oilcake). These TOP10 products account for $81 \%$ of all agri-food exports from
Ukraine [5].

Let's consider the commodity structure of exports of agricultural products. In the structure of exports (according to the results of 2019), the following commodity groups are the largest: cereal crops $(36 \%)$, oil $(18 \%)$, oilseeds $(10 \%)$, milk and dairy products $(4 \%)$.

At the same time, in 2019, compared to the same period in 2018, there was a significant decrease in exports of the following commodity items: barley - by $48 \%$ (by $\$ 675$ million), rape seeds - by $46 \%$ (by $\$ 586$ million), residues and waste from food industry- by $34 \%$ (by $\$ 169$ million), condensed milk - in 3 times (by $\$ 138$ million), cheese - by $25 \%$ (by $\$ 101$ million), wheat flour - in 3 times (by $\$ 80$ million) (Figure 2) [5-7]. 

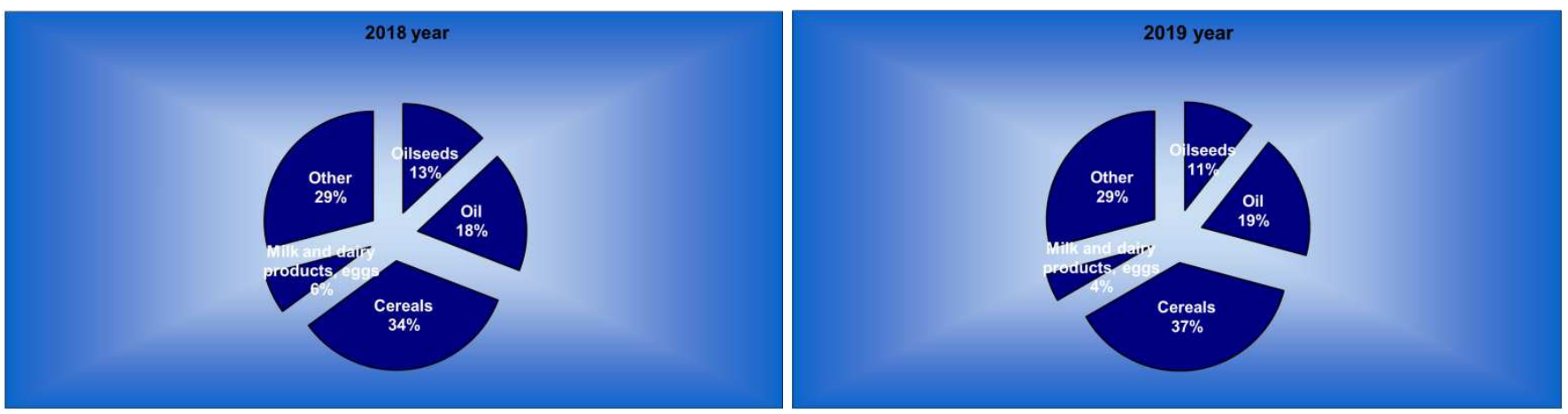

Source: [6]

Figure 2. Structure of export of agricultural products, \%.

The main market for the sale of Ukrainian agricultural products remains the Asian market, which slightly reduced its share in the structure of Ukrainian exports from $45 \%$ in 2017 to $44.6 \%$ in 2018 . The main partner countries from Asia in 2018 were India, Turkey and China. In second place - the EU countries, with a share of $33 \%$, where the main partners are the Netherlands, Spain and Italy. Among the top three are African countries, which in turn occupy $12.3 \%$. The main partners from Africa are Egypt, Tunisia and Morocco [5-8].
After the 2012-13 crisis, import also has shown a decline. However, since 2016, there was an increase in Ukraine's import purchases, both of total products and agri-food products. In 2017, imports of agricultural products increased by $10.5 \%$ compared to 2016 and reached $\$ 4.3$ billion. And according to the results of 2018, total exports of products from Ukraine amounted to $\$ 56.9$ billion, which is $14.7 \%$ more than in 2017. At that time, an agri-food import during this period increased by $18.6 \%$ and was $\$ 5.1$ billion [6].

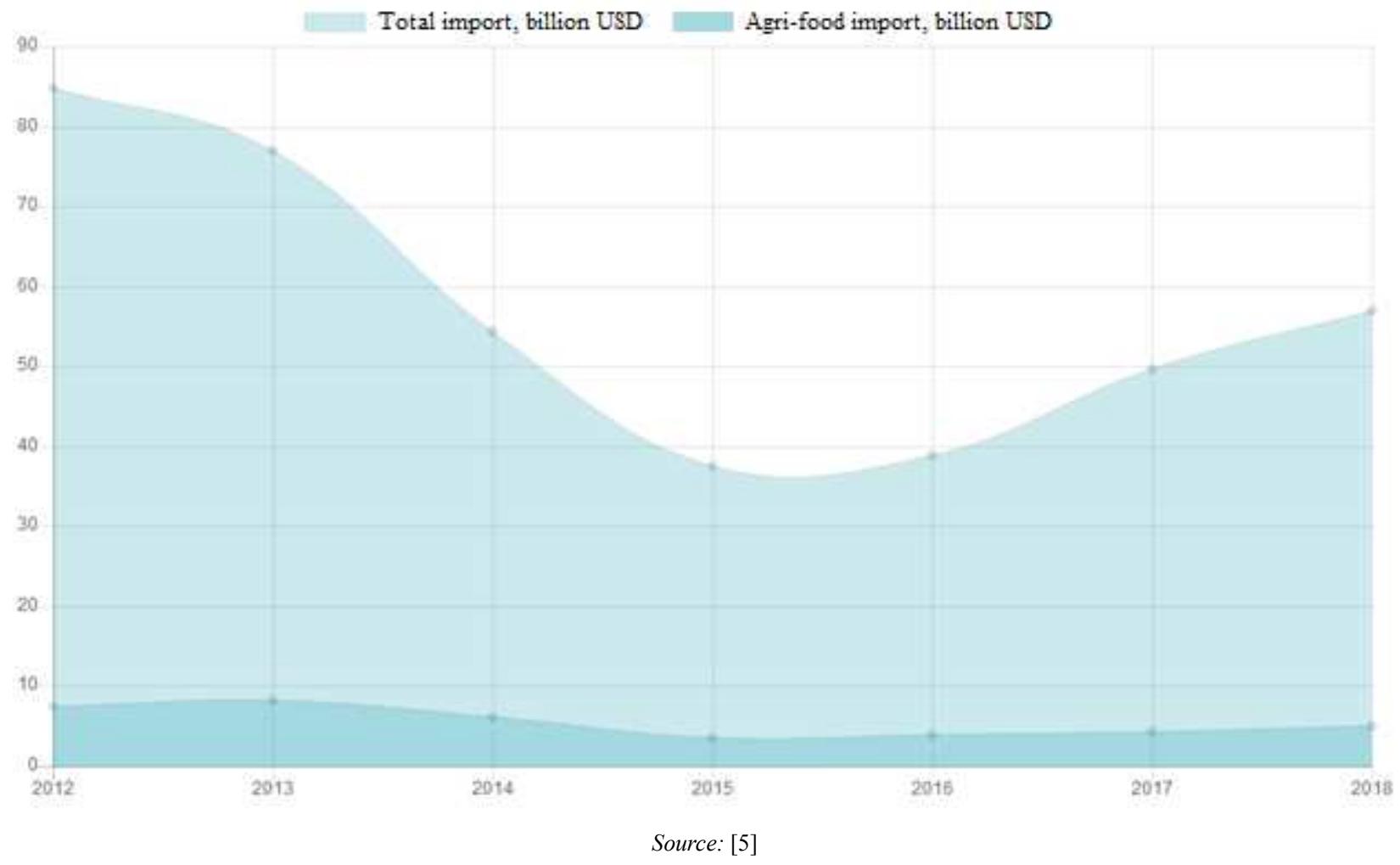

Figure 3. Dynamics of volumes in total import and Ukraine's agricultural sector import, 2012-2018 (billion USD).

The share of imports in the total volume of foreign trade in agricultural sector's products in 2019 was $34.6 \%$.

Within the commodity structure of imports of agricultural products into Ukraine, the following commodity groups are the largest: fruit and nuts $(12 \%)$, meat and by-products (11\%), fish and fish products $(9 \%)$, tobacco $(9 \%)$, etc. At the same time, the share of crop products in imports is $72 \%$, livestock products $-28 \%[5,6,9-11]$.

The most increase in imports in 2019 compared to the same period in 2018 was in the following products: citrus fruits (by $\$ 42$ million), butter (by $\$ 35$ million), apples, pears (by $\$ 32$ million), sugar (by 28 million), condensed milk (by $\$ 12.8$ million), tomatoes (by $\$ 12$ million), and lard (by $\$ 10.5$ million) (Figure 4) [12-14]. 

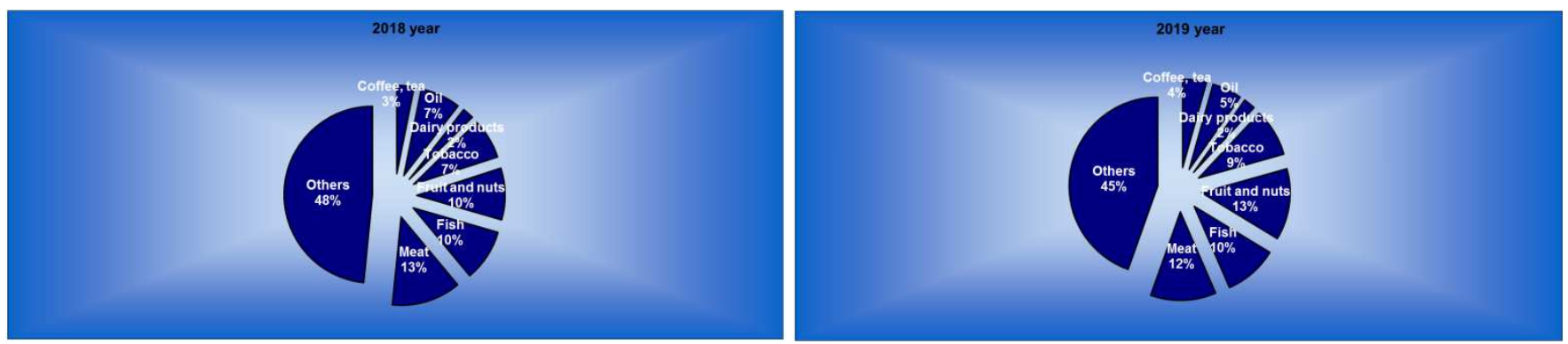

Source: [6]

Figure 4. Structure of imports of agricultural products, $\%$.

Thus, the cereal crops products have a significant share in the commodity structure of exports.

Over the recent years, Ukraine is raising its imports from Poland, which takes first place in the structure of Ukraine's agri-food imports. For the whole of 2018, imports from this country amounted to $\$ 469.7$ million. In second place is Germany - \$435.8 million, and Turkey takes the third place - \$371.6 million. Overall, the top 10 countries-suppliers of agri-food products into Ukraine account for $51 \%$ of all agrifood imports in Ukraine [5, 15].

\section{Conclusion}

In general, the following conclusion could be drawn by summarizing all of the above that despite the existence of an export strategy in the state, negotiations on free trade areas, free trade area agreements, yields and favorable prices in the world markets, the amount of trading partners, the result of foreign trade is negative. Therefore, until Ukraine exports raw materials, its revenues will depend solely on the conjuncture of the world markets. From year to year, Ukraine hopes solely for a favorable situation in foreign markets. Exactly the raw material type of the Ukrainian economy is the main reason that imports into Ukraine are steadily ahead of its exports.

With all the achievements of Ukrainian exporters, it continues to increase its imports much faster than exports. But stimulating the production of high value-added goods, supporting the growth of domestic small and medium-sized businesses and attracting investors that are ready to open manufacture in Ukraine are obvious steps to change the trade balance into a positive way.

\section{References}

[1] Kireev, A. (2002). International Economics. Part I. International microeconomics: movement of goods and factors of production [Mezhdunarodnaya ekonomika. Part I. Mezhdunarodnaya mikroekonomika: dvizhenie tovarov I faktorov proizvodstva]. Moscow: International Attitude.

[2] Kredysov, A., \& Babenko, V. (2003). Polityka stymuliuvannia eksportu ta yii instrumenty [Politics of stimulating export and its tools]. Ekonomika Ukrainy, 2, 4-7.

[3] Shpichak, O. O. (2004). Opodatkuvannia eksportno- importnykh operatsii z produktsiieiu roslynnytstva [Taxation of export-import operations with crop production]. Kyiv: NNCIAE.

[4] Filipenko, A. S., \& Verhun, V. A. (1996). Ekonomika zarubizhnykh krain [The economy of foreign countries]. Kyiv: Lybid, 416.

[5] Ukrainian Agribusiness Club (2018). The main indicators of foreign trade in Ukraine. Retrieved from http://ucab.ua/ua/doing_agribusiness/zovnishni_rinki/osnovni _pokazniki_zovnishnoi_torgivli_ukraini

[6] Statistics, Economics, Politics, Persons (2019). Rysky vneshnei torhovly Ukrayni [Risks of Ukraine's Foreign Trade]. Retrieved from https://zet.in.ua/statistika-2/eksportimport/riski-vneshnej-torgovli-ukrainy/

[7] The Common Agricultural Policy Explained. European Commission Directorate-General for Agriculture and Rural Development. Retrieved from http://ec.europa.eu/agriculture/publi/capexplained/cap_en.pdf

[8] European commission. Retrieved from http://ec.europa.eu/index_en.htm

[9] Regulation (EC) No 450/2008 of the European Parliament and of the Council of 23 April 2008 laying down the Community Customs Code (Modernised Customs Code). (2008). Official journal of the European Union, L 145/1. Retrieved from https://publications.europa.eu/en/publication-detail//publication/3ac826c5-29db-4029-ba3d57a52937609c/language-en

[10] Sharma, R. (2003). The Transmission of World Price Signals: Concepts, Issues, and Some Evidence from Asian Cereal Markets. In: Tangermann, S. and Burgeat, E. (eds.), Agricultural Trade and Poverty: Making Policy Analysis Count, Paris, Organisation for Economic Co-operation and Development, pp. 60-141.

[11] Melnyk, M., Korcelli-Olejniczak, E., \& Chorna, N. (2018). Development of regional IT clusters in Ukraine: institutional and investment dimensions. Economic Annals-XXI, 173, 9-10.

[12] Shevchenko, N. Yu. (2015). Osnovni chynnyky vplyvu na podatkovi nadkhodzhennia vid zovnishnoekonomichnykh operatsii z produktsiieiu ahropromyslovoho vyrobnytstva [The main factors influencing tax revenues from foreign economic operations with products of agro-industrial production]. Scientific Bulletin of NULES of Ukraine, 231.

[13] Lemishko O. O. (2015). Statistical estimation of the functional dependence of GDP growth rate and capital components. Actual problems of the economy (Aktualni problemy ekonomiky, 12, 377-389. 
[14] Lemishko, O. O. (2016/2). The Effect of Financial Policies on the Effectiveness of Agricultural Production. Actual problems of the economy (Aktualni problemy ekonomiky), $12,411-424$.
[15] Choi, K., \& Lim, S. (2019). A reappraisal of strategic trade policies with the endogenous mode of competition under vertical structures. Journal of international trade \& economic development, 28, 11-29. doi: https://doi.org/10.1080/09638199.2018.1482948. 